\title{
Hereditary Coagulation Factor Deficiency
}

National Cancer Institute

\section{Source}

National Cancer Institute. Hereditary Coagulation Factor Deficiency. NCI Thesaurus.

Code C98942.

An inherited blood coagulation disorder characterized by deficiency of one of the coagulation factors, resulting in bleeding. 